\title{
Biochar efficiency in the removal of heavy metals
}

\author{
Denise Domingos dos Santos Martinsa*, Juan Carlos Valdés Serrab, Joel Carlos Zukowski \\ Juniora, Marcelo Mendes Pedrozac \\ a Programa de Pós-Graduação em Engenharia Ambiental, Universidade Federal do Tocantins, Palmas, 77001-090, Tocantins, Brazil.* \\ denisedsm@gmail.com \\ b Laboratório de Materiais Compósitos, Universidade Federal do Tocantins, Palmas, 77001-090, Tocantins, Brazil. \\ c Instituto Federal do Tocantins, Palmas, 77020-450, Tocantins, Brazil.
}

Received: August 16, 2019 / Accepted: September 5, 2019 / Published online: September 30, 2019

\begin{abstract}
Toxic metals are naturally present in the environment even if there is no anthropic action. Several methods are used for the removal of these metals from water and effluents, such as: chemical precipitation, oxidation/reduction, filtration, ion exchange, membrane separation, and adsorption. Biosorption stands out as an effective treatment because it has a high rate of renewal in nature, low production costs, and high removal of metals due to the possibility of recovery of the contaminant, either by incinerating the biomass or by desorbing it. Thus, this study identified some biochars used as adsorbents for the removal of copper, lead, chromium, and mercury in water. It can be concluded from this study that adsorption is a very efficient technique for removing or recovering heavy metals from the environment. These biocarbons are alternatives that can replace commercial activated carbon because, besides having a low production cost, they have been shown to efficiently remove metal ions, ensuring an effective treatment in compliance with effluent release standards.
\end{abstract}

Keywords: Adsorption, adsorbents, biomass, activated carbon.

\section{Eficiência de biocarvões na remoção de metais pesados}

\section{Resumo}

Os metais tóxicos estão presentes naturalmente no meio ambiente mesmo que não haja ação antrópica. Vários métodos são utilizados para a remoção desses metais presentes na água e efluentes, tais como: precipitação química, oxidação/redução, filtração, troca iônica, separação por membranas e adsorção. A biossorção se destaca como um tratamento eficaz por possuir alta taxa de renovação na natureza, baixos custos de obtenção, altas remoções de metais e, devido à possibilidade da recuperação do contaminante, seja incinerando a biomassa ou realizando a sua dessorção. Dessa forma, o objetivo deste estudo foi identificar alguns biocarvões utilizados como adsorventes para a remoção dos metais cobre, chumbo, cromo e mercúrio em água. Através deste estudo pode-se concluir que a adsorção é uma técnica que se mostra bastante eficiente na remoção ou recuperação de metais pesados do meio ambiente. Esses biocarvões são alternativas que podem substituir o carvão ativado comercial, pois a além de ter um baixo custo de produção mostraram ter eficiência na remoção dos íons dos metais de forma a garantir o tratamento eficaz atendendo aos parâmetros legais de lançamento de efluentes.

Palavras-chave: Adsorção, adsorvente, biomassa, carvão ativado.

\section{Introduction}

Contamination of water bodies caused by the increase of toxic pollutants derived from anthropogenic effluents is a current environmental problem. Among the most hazardous wastes are heavy metals such as nickel and lead, which, although present in low concentrations, negatively impact aquatic biota and human health. The presence of these metals can lead to respiratory problems, immunological weakness, kidney and liver disorders, hypertension, genetic and neurological changes, cancer, and even death (Zhang et al., 2016).
Many metals are essential for the growth of all types of organisms, but they are required in low concentrations. Trace metals, especially, are among the most common environmental contaminants, with a remarkable behavior in various environmental compartments. Metals considered toxic represent a group of pollutants that require special treatment as they are neither chemically nor biologically degraded (Costa, Mendonça, \& Wysard Junior, 2017).

When released without pretreatment, these metals have high mobility in the environment and are bioaccumulative in the food chain (Lima, 2018). Thus, the control of effluent contaminants has been regulated by legislation at acceptable 
release limits, aiming at the safety of public health and the maintenance of a balanced environment (Souza, 2017).

Conventional methods have been implemented to remove heavy metals from industrial waters, including: precipitation, electrochemical treatment, membrane separation, evaporation, coagulation, among others. However, high costs, high sludge production, and incomplete removal make them ineffective and unfavorable (Lara, Tejada, Villabona, Arrieta, \& Conde, 2016).

In this context, with a view to reducing operating costs and improving operating times in water treatment, many studies have been conducted using abundant natural waste such as sea shells, crab shells, egg shells, seeds, fruit peels, palm oil and its residues, rice husks, zeolites, cocoa husks, corn cob, cassava and yam peel, orange peel, among others. Their effectiveness depends on the nature of the biomaterial used (Tejada-Tovar, Montiel \& Acevedo 2016).

Biochar is a solid material formed by thermochemical decomposition of biomass (Cha et al., 2016) and can also be defined as organic matter heated under limited oxygen conditions (Gondim, Muniz, Lima, \& Santos, 2018). The most important variables in this process are the temperature, biomass type, and atmosphere - inert or little oxidizing (Kim, Kim, Cho, \& Choi, 2012).

Thus, this research evaluated the main biochars used as adsorbents for the removal of metals (copper, lead, chromium, and mercury) in water for future application in effluent treatment systems.

\section{Technologies for metal removal in water}

In recent decades, the balance of aquatic ecosystems has been altered by increased discharges of organic and inorganic pollutants, especially heavy metals among the latter, which, unlike organic pollutants that can be metabolized by aquatic microbiota, are indestructible (Gunatilake, 2015). Heavy metals are naturally present in the environment even if there is no anthropic action. Reducing the impacts caused by soil and water pollution is fundamental for improving environmental quality and ensuring quality of life.

Several methods are used for removing heavy metals from water and effluents, such as: chemical precipitation, oxidation/reduction, filtration, ion exchange, membrane separation, and adsorption (Costa et al., 2017). However, when these methods are applied to effluents with low metal concentrations, they may demand high costs and have low removal efficiency, low selectivity, and high energy requirements (Modenes et al., 2013).

The high cost of major technologies for heavy metal removal, combined with high sludge and byproduct production, make these methods disadvantageous compared to the adsorption method. Notwithstanding, commercial activated carbon is still very expensive despite its easy recovery of heavy metals at low concentrations, possibility of adsorbent reuse, and low waste generation.

Among the alternatives involving adsorption processes, one of the most used for the removal of heavy metals in aqueous environment is activated carbon. According to Santos (2016), commercial activated carbon is one of the materials with high adsorption capacity for organic compounds, metals, among others, being widely used for wastewater treatment. However, losses during adsorbent recovery make it expensive to use.

For Hokkanen, Bhatnagar \& Sillanpaa (2016), the most important factors for adsorption to be economically viable are the efficiency (adsorption capacity) and the cost of the adsorbent used. Nonetheless, adsorption efficiency depends on several factors, including the initial concentration of the adsorbate under investigation, competition between pollutants in the effluent, the analytical method used for adsorption tests (batch method, column), among others.

Thus, biochar production in substitution of commercial activated carbon is of extreme environmental and industrial interest, as there is a range of residues that can be used to prepare adsorbents at a relatively low cost. Santos (2016) argues that, in some cases, there is the possibility of adsorbent recovery without loss of its physical and chemical identity.

\section{Biochar production and identification of the main biomasses used in this process}

Brazil has an extensive area of agricultural production, favored by good climate and relief conditions for many crops to grow (Eckert et al., 2013). Although most agroindustrial waste already has a defined application, the residual biomass from agricultural activities is not yet well used in Brazil. In many cases it is left for natural decomposition in the soil, without harnessing the energy contained therein and producing carbon dioxide and methane (Rambo, Schmidt, \& Ferreira, 2015).

The techniques used to convert biomass into carbon can be classified into two main groups: biochemical conversion, which degrades biomass with enzymes and microorganisms; and thermochemical conversion, in which biomass is degraded by heating (Kubilay, Selhan, \& Sema, 2014).

For Tripathi, Sahu, \& Ganesan, (2016), biochemical conversion technology is less expensive and more environmentally friendly compared to the thermochemical conversion technique, but the production rate and yield is quite low. In addition, one of the biggest challenges in biochemical conversion is the rapid and complete conversion of biomass in an efficient manner. This limitation of the biochemical technique has diverted the attention of some researchers to thermochemical techniques (Saletnik et al., 2019).

Thermochemical conversion technology is based on the thermal degradation of the precursor material. This process includes conventional carbonization or pyrolysis, hydrothermal carbonization, combustion, and gasification (Kubilay et al., 2014). In biochar production, thermal degradation processes are governed mainly by the pyrolysis temperature, the time the material remains in the reactor, and the heating rate (Trazzi, Higa, Dieckow, Mangrich, \& Higa, 2018).

The use of biomass, combined with thermochemical synthesis, has as advantages in obtaining new carbonaceous materials with different applications the low cost, high availability in nature, and rapid regeneration (Santos, 2016). 
For Novotny, Maia, Carvalho, and Madari (2015), various organic materials are suitable for use as raw materials in thermal processing, from agricultural and wood biomass to any available agricultural and industrial waste (peels, straw, seeds, bagasse, nutshell, wood shavings, etc.) and even municipal solid wastes.

The so-called biochar produced in pyrolysis contains a high energy, and is in some cases comparable to the coal used in industries due to its microporous structure and high carbon content. In agriculture, it is used to improve soil quality and increase the rate of carbon sequestration. It slows down the rate of nutrient decomposition and consequently improves soil quality. In the adsorption industry, it is used to remove heavy metals such as $\mathrm{Cr}, \mathrm{Cd}, \mathrm{Ni}, \mathrm{Hg}, \mathrm{Pb}$, and organic compounds (Tripathi et al., 2016).

In this sense, there is a growing interest in the search for low cost alternative materials that can be used in the production of activated charcoal, including agricultural residues that offer a promising future in adsorption processes (biosorption). For that purpose, the following materials are highlighted: rice husk (Doria Herrera, Uribe, Anaguano, \& Suarez, 2016), orange peel (Tejada-Tovar, Ortiz \& Patenina, 2015), corn cob (Lopes et al., 2013), sugarcane bagasse (Ferreira et al., 2015), and the coconut fiber-chitosan composite material (Costa et al., 2017).

\section{Biochar efficiency in removing metals from water}

A wide variety of solid materials can be used as adsorbents. One of the most critical points in the use of adsorbents is the suitability of its porous structure, which directly interferes with the diffusion phenomenon, reflecting on the surface area of the solid and thus influencing the values of adsorption velocity and total adsorption capacity (Souza, 2017).

Some studies are being done to evaluate the adsorption capacity and efficiency in the removal of copper, lead, chromium, and mercury ions in aqueous environments. Below are some references depicting the most commonly used biomass in the production of biocarbons for the purpose of being adsorbed to heavy metal ions.

\section{Copper}

Copper is one of the few metals that occur in nature in its pure state. Its use has been widespread since ancient times. The element can be found in nature in different forms of mineral compounds, such as $\mathrm{CuS}, \mathrm{CuFeS}_{2}, \mathrm{CuSO}_{4}$, among others (Melo, Coscione, Abreu, Puga, \& Camargo, 2013).

Biochars produced from Macadamia integrifolia Maiden $\&$ Betche (macadamia nut endocarp) and Psidium guajava $\mathrm{L}$. (guava seed) were compared with commercial charcoal for the removal of copper ion in aqueous solution. The optimum carbonization temperature found was $720^{\circ} \mathrm{C}$ in an industrial nitrogen atmosphere, with adsorption capacity of $3.48 \mathrm{mg} \mathrm{g}^{-1}$ for macadamia endocarp biochar and $1.23 \mathrm{mg} \mathrm{g}^{-1}$ for guava seed biochar. The adsorption capacity of commercial coal was $4.84 \mathrm{mg} \mathrm{g}^{-1}$ (Rocha, Luz, Lena, \& Bruña-Romero, 2006).

Atriplex Nummularia Lindl (saltbush) and Colocasia Antiquorum Schott (taioba-brava) leaves were used by
Lucena, Silva, Honório and Santos (2012), who verified the adsorption capacity for $\mathrm{Cu}^{+2}$ ions from aqueous solutions. At concentrations above $700 \mathrm{mg} \mathrm{L}^{-1}$, taioba-brava presented higher $\mathrm{Cu}^{2+}$ removal percentages than saltbush. Large levels of oxalate ions $\left(\mathrm{C}_{2} \mathrm{O}_{4}{ }^{-2}\right)$ are believed to be present in the leaf composition of these bioadsorbents. Adsorption capacity and removal efficiency were $8.89 \mathrm{mg} \mathrm{g}^{-1}$ and $4.47 \mathrm{mg} \mathrm{g}^{-1}, 98.82 \%$ and $99.88 \%$ for the bioadsorbent produced from the leaves of saltbush and taioba-brava, respectively.

The biochar produced from rice husk in a muffle furnace with a temperature of $500{ }^{\circ} \mathrm{C}$ was activated with acid and base (phosphoric acid - $\mathrm{H}_{3} \mathrm{PO}_{4}$ and potassium hydroxide - $\mathrm{KOH}$ ) to evaluate which one has better activating function for copper removal in aqueous environment. Adsorption capacity was $3.20 \mathrm{mg} \mathrm{g}^{-1}$ for $\mathrm{KOH}$-activated carbon and $2.2 \mathrm{mg} \mathrm{g}^{-1}$ for $\mathrm{H}_{3} \mathrm{PO}_{4}$-activated carbon (Miguel, 2017).

Several other studies on copper removal are reported in the literature for biocarbons produced from Mauritia flexuosa $\mathrm{L}$. f. (buriti) (Pinto, Silva, \& Saraiva, 2013), Saccharum officinarum L. (sugarcane) (Ferreira et al., 2015; Silva, 2017), Eichhornia crassipes (water hyacinth) (Lima, 2018), and Coffea canephora (coffee) (Oliveira, 2018).

The adsorption capacity of these biocarbons ranged from 4.96 to $6.31 \mathrm{mg} \mathrm{g}^{-1}$, corresponding to removal efficiencies of 85 to $99.79 \%$. Table 1 shows these adsorbents used for copper removal, depicting the adsorption capacity and efficiency compared to a commercial activated carbon.

Nine biomasses used for biochar production for the purpose of adsorbing copper ions in aqueous environment were observed. Sugarcane residues were used according to Ferreira et al. (2015) and Silva (2017). Each of these authors used a different activator for biochar and all results showed efficiency in removing copper ion.

In turn, Miguel (2017) used rice husk in the production of two biochars, one with basic activation and another with acid activation. Although base-activated biochar is more efficient in removing copper ions in aqueous environment, both have efficiencies above $92 \%$.

Biochars produced from taioba-brava, saltbush, buriti lumps, and water hyacinth were also more efficient in removing copper ions compared to commercial activated carbon. The bioadsorbent produced from coffee straw showed the lowest removal efficiency and its use in metal removal was not recommended.

The study with biochars produced from guava and macadamia nut seeds showed that these adsorbents had an adsorption capacity lower than the adsorption capacity of commercial activated carbon despite the $93 \%$ efficiency in the removal of copper ions by the guava seed biochar and $99.1 \%$ efficiency for biochar produced from macadamia nut.

Thus, it should be noted whether the biomass used for biochar production will adsorb copper ions in aqueous environment so as to meet the parameters established by environmental legislation and whether its use is advantageous compared to other conventional methods.

Lead 
Lead has long-known toxic effects. It is widely used in accumulators, batteries, alloys, pigments, among others ( $\mathrm{Li}$ et al., 2016). In the human body, lead accumulates in the kidneys, liver, brain, and especially in the bones.

Activated charcoal produced from Moringa oleifera (moringa) seed husk was physically activated with steam and carbon dioxide to be used as a lead ion adsorbent (Nogueira, 2010). The adsorption characteristics of the produced biochar were compared with those from a commercially available charcoal. The maximum $\mathrm{Pb}$ adsorption capacity (Qmax) for coal was $136 \mathrm{mg} \mathrm{g}^{-1}$ for $750 / \mathrm{H}_{2} \mathrm{O} / 10,15.22 \mathrm{mg} \mathrm{g}^{-1}$ for $950 / \mathrm{CO}_{2} / 30$, and $4.32 \mathrm{mg} \mathrm{g}^{-1}$ for the trademark Synth. On a laboratory scale, the fixed bed column had good $\mathrm{Pb}$ adsorption capacity, $87.41 \mathrm{mg} \mathrm{g}^{-1}$, which can be useful for the treatment of water in communities that cultivate moringa.

Manihot esculenta (cassava) and Dioscorea spp. (yam) peels were chemically modified with citric acid and their performance for $\mathrm{Pb}^{+2}$ adsorption was evaluated. Adsorption tests were carried out using a particle size between 0.5 and 1 $\mathrm{mm}$, and $\mathrm{pH}=6$. The determination of the remaining metal in solution was measured by atomic absorption spectroscopy. Adsorption capacities were 52.34 and $98.36 \mathrm{mg} \mathrm{g}^{-1}$ for cassava and yam peels, respectively (Tejada-Tovar et al., 2016).

The applicability of activated charcoal produced from Citrus sinensis L. Osbeck (orange) peel for lead adsorption in aqueous solution was determined by Ali \& Abdel-Satar (2017). The biochar was obtained at $400{ }^{\circ} \mathrm{C}$ and activated with zinc chloride $\left(\mathrm{ZnCl}_{2}\right)$. The optimum $\mathrm{pH}$ values for adsorption capacity and efficiency in the removal of heavy metal ions were 5-6. The optimum soaking time was 120 min for $\mathrm{Pb}^{+2}$ and the optimum adsorbent dosage for removal of the studied metal was $2 \mathrm{~g}$, with $96 \%$ lead removal efficiency.

Table 1. Adsorbents and their activator, dosages, efficiency (\%) and adsorption capacity $\left(\mathrm{mg} \mathrm{g}^{-1}\right)$ used for copper and lead removal in aqueous environment.

\begin{tabular}{|c|c|c|c|c|c|}
\hline Adsorbent & Dosage* & Activator & Efficiency & $\begin{array}{l}\text { Adsorption } \\
\text { capacity }\end{array}$ & Reference \\
\hline \multicolumn{6}{|c|}{ copper } \\
\hline Conventional & $0.1 \mathrm{~g} / 50 \mathrm{ml}$ & $\mathrm{Nd}^{* *}$ & 99.87 & 4.84 & Rocha et al. (2006) \\
\hline Guava seed & $0.1 \mathrm{~g} / 50 \mathrm{ml}$ & $\mathrm{N}_{2}$ & 93.04 & 1.23 & Rocha et al. (2006) \\
\hline Macadamia nut & $0.1 \mathrm{~g} / 50 \mathrm{ml}$ & $\mathrm{N}_{2}$ & 99.01 & 3.48 & Rocha et al. (2006) \\
\hline Taioba-brava & $0.5 \mathrm{~g} / 250 \mathrm{ml}$ & Physical & 99.88 & 4.47 & Lucena et al. (2012) \\
\hline Saltbush & $0.5 \mathrm{~g} / 250 \mathrm{ml}$ & Physical & 98.82 & 8.89 & Lucena et al. (2012) \\
\hline Buriti lumps & $1.0 \mathrm{~g} / 100 \mathrm{ml}$ & Physical & 99.21 & 4.96 & Pinto et al. (2013) \\
\hline Sugarcane & $40 \mathrm{mg} / 20 \mathrm{ml}$ & $\mathrm{HCl}$ & 99.53 & 3.56 & Ferreira et al. (2015) \\
\hline Rice husk & $0.2 \mathrm{~g} / 20 \mathrm{ml}$ & $\mathrm{H}_{3} \mathrm{PO}_{4}$ & 92.9 & 2.20 & Miguel (2017) \\
\hline Rice husk & $0.2 \mathrm{~g} / 20 \mathrm{ml}$ & $\mathrm{KOH}$ & 99.6 & 3.20 & Miguel (2017) \\
\hline Sugarcane & $0.25 \mathrm{~g} / 25 \mathrm{ml}$ & $\mathrm{H}_{3} \mathrm{PO}_{4}$ & 99.79 & $\mathrm{Nd}^{* *}$ & Silva (2017) \\
\hline Water hyacinth & $100 \mathrm{mg} / 10 \mathrm{ml}$ & $\mathrm{N}_{2}$ & 90.8 & 6.31 & Lima (2018) \\
\hline Coffee straw & $1.5 \mathrm{~g} / 50 \mathrm{ml}$ & $\mathrm{N}_{2}$ & 85 & $\mathrm{Nd}^{* *}$ & Oliveira (2018) \\
\hline \multicolumn{6}{|c|}{ lead } \\
\hline Commercial & $1 \mathrm{~g} / 100 \mathrm{ml}$ & $\mathrm{Nd}^{* *}$ & 98.69 & 4.32 & Nogueira (2010) \\
\hline Babassu coconut shell & $0.1 \mathrm{~g} / 200 \mathrm{ml}$ & $\mathrm{H}_{2} \mathrm{O}$ & 98.87 & 30.3 & Golin (2007) \\
\hline Moringa seed husk & $1 \mathrm{~g} / 100 \mathrm{ml}$ & $\mathrm{H}_{2} \mathrm{O}$ & 98.21 & 136.98 & Nogueira (2010) \\
\hline Moringa seed husk & $1 \mathrm{~g} / 100 \mathrm{ml}$ & $\mathrm{CO}_{2}$ & 99.14 & 15.22 & Nogueira (2010) \\
\hline Green coconut & $17 \mathrm{~g} / 1 \mathrm{~L}$ & $\mathrm{NaOH}$ & 98.79 & $\mathrm{Nd}^{* *}$ & Ferreira et al. (2012) \\
\hline Sugarcane & $1 \mathrm{~g} / 20 \mathrm{ml}$ & $\mathrm{HNO}_{3}$ & 96 & 20.77 & Figueredo et al. (2017) \\
\hline Pine nut shell & $90 \mathrm{mg} / 30 \mathrm{ml}$ & $\mathrm{N}_{2}$ & 98.5 & 73.99 & Lage Junior (2016) \\
\hline Cocoa husk & $8 \mathrm{~g} / 8 \mathrm{~L}$ & Physical & 91.32 & 0.07 & Lara et al. (2016) \\
\hline Yam peel & $40 \mathrm{mg} / 200 \mathrm{ml}$ & $\mathrm{C}_{6} \mathrm{H}_{8} \mathrm{O}_{7}$ & 98.04 & 98.36 & Tejada-Tovar et al. (2016) \\
\hline Cassava peel & $40 \mathrm{mg} / 200 \mathrm{ml}$ & $\mathrm{C}_{6} \mathrm{H}_{8} \mathrm{O}_{7}$ & 95.57 & 52.34 & Tejada-Tovar et al. (2016) \\
\hline Orange peel & $1 \mathrm{~g} / 100 \mathrm{ml}$ & $\mathrm{ZnCl}_{2}$ & 96 & $\mathrm{Nd}^{* *}$ & Ali \& Abdel-Satar (2017) \\
\hline Sugarcane & $0.5 \mathrm{mg} / 100 \mathrm{ml}$ & $\mathrm{H}_{2} \mathrm{SO}_{4}$ & 54.74 & 0.4486 & Ferreira (2018) \\
\hline
\end{tabular}

*Dosage: refers to the amount of adsorbent / amount of adsorbate. ** Nd: parameter not determined in the study.

Studies in the literature mention biocarbons for the removal of lead ions in water. These biocarbons can be produced from Orbignya martiana (babassu) (Golin, 2007); Cocos nucifera L. (green coconut) (Ferreira, Silva, Lima, \&
Begnini, 2012); Saccharum officinarum L. (sugarcane) (Figueredo, Costa, Melo, Siebeneichlerd, \& Tronto, 2017; Ferreira, 2018); Araucaria angustifolia (pine nut) (Lage 
Junior, 2016); Theobroma cacao (cocoa) (Lara, Tejada, Villabona, Arrieta \& Conde, 2016).

The adsorption capacity of these biocarbons ranged from 0.07 to $73.99 \mathrm{mg} \mathrm{g}^{-1}$, corresponding to removal efficiencies of 54.74 to $98.87 \%$. Table 1 shows the biomasses being studied for biochar production aiming at lead adsorption in aqueous environment, as well as their efficiency and adsorption capacity.

As can be observed, several biomasses are being studied for the purpose of producing biochars aiming at adsorption of lead ions in water. Figueredo et al. (2017) and Ferreira (2018) used sugarcane residues to produce biochars with different activation conditions and found very different efficiencies for removing lead in aqueous solutions. This demonstrates that a certain method can render the produced biochar unviable for use in lead adsorption due to its low efficiency.

The study carried out with biochar production from orange peel did not show the adsorption capacity of the charcoal produced, but its removal efficiency was low. Biochars produced from cassava peel and cocoa husk also showed low removal efficiency for lead ions, and cocoa husk biochar showed the lowest adsorption capacity, with only $0.07 \mathrm{mg} \mathrm{g}^{-1}$.

Adsorbents produced from babassu, steam-activated moringa, pine nut shell, and yam peel had their efficiencies slightly below the efficiency of commercial activated carbon, but their use may be recommended. Of the cited biochars, only those produced from green coconut and $\mathrm{CO}_{2}$-activated moringa had higher removal efficiency than the commercial activated charcoal.

Thus, when seeking a biomass for biochar production aiming at adsorption of lead ions in water, consideration should be given to the method for obtaining the adsorbent so as to achieve better yield, removal efficiency, and maximum adsorption capacity for metal ions.

\section{Chromium}

Chromium is widely used in various industries such as metallurgy, electroplating, leather tanning, wood protection, and in the manufacture of dyes and pigments. Under environmental conditions, chromium exists mainly in the forms of $\mathrm{Cr}^{+3}$ and $\mathrm{Cr}^{+4}$. Trivalent chromium $\left(\mathrm{Cr}^{+3}\right)$ is an essential element for humans, participating in glucose and lipid metabolism (Pan, Jiang, \& Xu, 2013). On the other hand, the presence of tetravalent chromium $\left(\mathrm{Cr}^{+4}\right)$ even at low concentrations becomes toxic through dermal or oral exposure. This form of chromium has mobility in the environment and shows carcinogenic potential (Geelhoed et al., 2002).

The adsorption of $\mathrm{Cr}^{+4}$ by commercial granular activated carbon as adsorbent of dilute solutions employing a batch adsorption system with controlled $\mathrm{pH}$ was evaluated by Souza, Carvalho, Garcia Júnior and Sena, (2009). Under optimum conditions $(\mathrm{pH} \mathrm{6}$, equilibration time of 90 minutes, and $2 \mathrm{~g} / 50 \mathrm{ml}$ dosage), the activated charcoal showed adsorption capacity of $0.54 \mathrm{mg} \mathrm{g}^{-1}$ and removal efficiency of $98 \%$.

Biochar produced from the biomass of Eichhornia crassipes (water hyacinth) root was used to evaluate the removal of $\mathrm{Cr}$ (VI) from aqueous solutions. Maximum removal capacity was $36.34 \mathrm{mg} \mathrm{g}^{-1}$ under ideal conditions ( $\mathrm{pH}$ 4.5, contact time of 30 minutes, and $7 \mathrm{~g} \mathrm{~L}^{-1}$ biomass dosage), with $\mathrm{Cr}$ (VI) removal efficiency of $92.24 \%$ (Giri, Patel, \& Mandal, 2012).

The potential of Malpighia emaeginata (acerola) seeds for chromium removal was evaluated by Rezende et al. (2014). The adsorbent was obtained by heat treatment at $170^{\circ} \mathrm{C}$, being then crushed and classified by particle size. The experiments were performed at $25 \pm 1{ }^{\circ} \mathrm{C}$, with varying contact time (10140 minutes), $\mathrm{pH} 2-8$, and adsorbent mass of 0.1-0.6 grams. The average removal of $\mathrm{Cr}(\mathrm{VI})$ was $66 \%$ using $0.1 \mathrm{~g}$ of biosorbent, $\mathrm{pH} 2.0$, and contact time of $120 \mathrm{~min}$. The chromium adsorption capacity of the biochar was not presented.

Other biomasses are also being used for the removal of chromium in aqueous environment, such as Saccharum officinarum L. (sugarcane) (Ferreira et al., 2015; Ferreira, 2018); Elaeis guineensis (African palm) (Tejada-Tovar et al., 2015); Dioscorea spp. (yam) (Tejada-Tovar et al., 2015); Juglans regia L. (walnut shells) (Altun \& Kar, 2016); Zea mays (corn) (Gupta, Ram, Bala, Kapur, \& Mondal, 2018); Oryza sativa (rice) (Miguel, 2017). The adsorption capacity of these biocarbons ranged from 0.2884 to $41.57 \mathrm{mg} \mathrm{g}^{-1}$, corresponding to removal efficiencies of 29.13 to $99.97 \%$.

Table 2 depicts the removal efficiencies and adsorption capacity for chrome ions by adsorbents produced from biomass.

As can be seen, many different biomasses are being used in the production of biochar for chromium ion adsorption in aqueous environment. Although the adsorption capacity of commercial activated carbon is very low, its removal efficiency is high and most of the biochars produced did not show equal or superior efficiency in the removal of metal compared to conventional coal.

Biochars produced from acerola seeds, yam peel, African palm bagasse, walnut shells, rice residues, and corn cob are not recommended for the removal of chromium ions according to the methods used in the cited studies, since their efficiency in removing the metal did not reach $90 \%$ in any of the cases.

The water hyacinth root biomass studied by Giri et al. (2012) for biochar production showed $92.24 \%$ efficiency in the removal of chromium ions. This parameter is not sufficient to recommend its use as a substitute for commercial activated carbon.

Sugarcane residues were used by Ferreira et al. (2015) and Ferreira (2018) with different biochar production methods, which resulted in very different removal efficiencies and adsorption capacity for chromium ion. The adsorbent produced by hydrochloric acid-activated biomass showed the best removal efficiency, even higher than the removal efficiency by commercial activated carbon, and its use is recommended.

Thus, it is understood that the production of a biochar being economically viable is not enough, the methodology employed must also be efficient in the adsorption of chromium from the water and meet the environmental standards.

\section{Mercury}


Mercury has a highly toxic action, especially in its organic form as methylmercury, which mostly affects the central nervous system, accumulating in the brain from the bloodstream and in kidney and liver cells (Haris, Aris, \& Mokhtar, 2017).

Activated carbon from the bamboo species Bambusa vulgaris Striata was used as adsorbent by Gonzales \& PliegoCuervo (2014). Studies have shown that a $0.6 \mathrm{~g} / \mathrm{L}$ activated carbon dosage, $9 \mathrm{pH}$ solution, and 16 hours equilibration time result in a mercury adsorption capacity of $248.05 \mathrm{mg} \mathrm{g}^{-1}$ and removal efficiency of $99.13 \%$.

Thirty-six biochars produced from distinct feedstocks at different temperatures were evaluated for their potential to remove mercury $(\mathrm{Hg})$ from aqueous solution at environmentally relevant concentrations (Liu, Ptacek, Blowes, \& Landis, 2016). Among the biomasses used, the following are highlighted: Gossypium hirsutum L. (cotton) seeds, Zea mays (corn cob), and Humulus lupulus (hops). Biochars were produced from biomass pyrolysis at $600{ }^{\circ} \mathrm{C}$. The individual value of the adsorption capacities was not determined and removal efficiencies were above $95 \%$.

Tang, Gong, \& Huang (2015) tested the adsorption characteristics of biochar obtained from slow $\left(600{ }^{\circ} \mathrm{C}\right)$ pyrolysis of Triticum spp. straw (wheat). The optimum $\mathrm{pH}$ was between 6.8-7.0, obtaining a removal efficiency of $98.1 \%$ for mercury ions. Equilibrium was reached within 48 hours, with adsorption capacity of $10.47 \mathrm{mg} \mathrm{g}^{-1}$.

Table 2. Adsorbents and their activator, dosages, efficiency (\%) and adsorption capacity $\left(\mathrm{mg} \mathrm{g}^{-1}\right)$ used for chromium and mercury removal in aqueous environment.

\begin{tabular}{|c|c|c|c|c|c|}
\hline Adsorbent & Dosage* & Activator & Efficiency & $\begin{array}{c}\text { Adsorption } \\
\text { capacity }\end{array}$ & Reference \\
\hline \multicolumn{6}{|c|}{ chromium } \\
\hline Conventional & $0.35 \mathrm{~g} / 50 \mathrm{ml}$ & $\mathrm{Nd}^{* *}$ & 98 & 0.54 & Souza et al. (2009) \\
\hline Water hyacinth & $7 \mathrm{~g} / \mathrm{L}$ & Physical & 92.24 & 36.34 & Giri et al. (2012) \\
\hline Acerola seeds & $1 \mathrm{~g} / 50 \mathrm{ml}$ & $\mathrm{Nd}^{* *}$ & 66 & $\mathrm{Nd}^{* *}$ & Rezende et al. (2014) \\
\hline Sugarcane & $10 \mathrm{mg} / 20 \mathrm{ml}$ & $\mathrm{HCl}$ & 99.97 & 5.26 & Ferreira et al. (2015) \\
\hline Yam peel & $40 \mathrm{mg} / 200 \mathrm{ml}$ & $\mathrm{C}_{6} \mathrm{H}_{8} \mathrm{O}_{7}$ & 88.7 & 25.01 & Tejada-Tovar et al. (2015) \\
\hline African palm bagasse & $40 \mathrm{mg} / 200 \mathrm{ml}$ & $\mathrm{C}_{6} \mathrm{H}_{8} \mathrm{O}_{7}$ & 58.8 & 41.57 & Tejada-Tovar et al. (2015) \\
\hline Walnut shells & $\mathrm{Nd}^{* *}$ & Physical & 80.47 & 36.55 & Altun \& Kar (2016) \\
\hline Rice residues & $3 \mathrm{~g} / 20 \mathrm{ml}$ & $\mathrm{H}_{3} \mathrm{PO}_{4}$ & 72 & 6.67 & Miguel (2017) \\
\hline Sugarcane & $0.5 \mathrm{mg} / 100 \mathrm{ml}$ & $\mathrm{H}_{2} \mathrm{SO}_{4}$ & 29.13 & 0.2884 & Ferreira (2018) \\
\hline Corn cob & $10 \mathrm{~g} 50 \mathrm{ml}$ & $\mathrm{H}_{3} \mathrm{PO}_{4}$ & 93 & 25.69 & Gupta et al. (2018) \\
\hline \multicolumn{6}{|c|}{ mercury } \\
\hline Conventional & $0.3 \mathrm{~g} / 50 \mathrm{ml}$ & $\mathrm{Nd}^{* *}$ & 99.9 & 4.77 & Tan et al. (2016) \\
\hline Apricot & $10 \mathrm{mg} / 50 \mathrm{ml}$ & $\mathrm{HCl}$ & 99.6 & 153 & Ekinci et al. (2002) \\
\hline Soybean stem & $0.01 \mathrm{~g} / 35 \mathrm{ml}$ & Physical & 74.5 & 86.4 & Kong et al. (2011) \\
\hline Bamboo & $0.6 \mathrm{~g} / \mathrm{L}$ & $\mathrm{H}_{2} \mathrm{O}$ & 99.13 & 248.05 & $\begin{array}{c}\text { Gonzales \& Pliego-Cuervo } \\
\text { (2014) }\end{array}$ \\
\hline Cocoa husk & $0.05 \mathrm{mg} / 50 \mathrm{ml}$ & $\mathrm{ZnCl}_{2}$ & 99.8 & 10 & Kede et al. (2015) \\
\hline Wheat straw & $5 \mathrm{~g} / 50 \mathrm{ml}$ & $\mathrm{N}_{2}$ & 98.1 & 10.47 & Tang et al. (2015) \\
\hline Hops & $0.8 \mathrm{~g} / 200 \mathrm{ml}$ & Physical & $>95 \%$ & $\mathrm{Nd}^{* *}$ & Liu et al. (2016) \\
\hline Corn cob & $0.8 \mathrm{~g} / 200 \mathrm{ml}$ & Physical & $>95 \%$ & $\mathrm{Nd}^{* *}$ & Liu et al. (2016) \\
\hline Cotton seed & $0.8 \mathrm{~g} / 200 \mathrm{ml}$ & Physical & $>95 \%$ & $\mathrm{Nd}^{* *}$ & Liu et al. (2016) \\
\hline Corn cob & $0.3 \mathrm{~g} / 50 \mathrm{ml}$ & $\mathrm{N}_{2}$ & 99.8 & 3.23 & Tan et al. (2016) \\
\hline
\end{tabular}

*Dosage: refers to the amount of adsorbent / amount of adsorbate. ** Nd: parameter not determined in the study.

Other biomasses are also being used for the removal of mercury in aqueous environment, such as Prunus armeniaca (apricot) (Ekinci et al., 2002); Glycine max L. (soybean) (Kong, He, Gao, Wu, \& Zhu, 2011); Theobroma cacao (cocoa) pod (Kede et al., 2015); Zea mays (corn) (Tan et al., 2016). The adsorption capacity of these biocarbons ranged from 4.77 to $86.4 \mathrm{mg} \mathrm{g}^{-1}$, corresponding to removal efficiencies of 74.5 to $99.9 \%$. Table 2 depicts the efficiencies and adsorption capacity of the cited biochars for mercury ions.

It can be observed that the biochar produced from soybean stem had the lowest removal efficiency for mercury ions, with only $74.5 \%$. An explanation for the low efficiencies in heavy metal removal is that, in the adsorption system, the characteristics of the biochar used, such as pore size, structure, specific surface area, or even insufficient contact time, can affect adsorption performance.

Biochars produced from cotton seeds, corn cob, and hops showed efficiencies greater than $95 \%$ in the removal of mercury ions, but below the removal efficiency of commercial activated carbon, thus their use should be seen with care so as not to prioritize the low cost of adsorbent production rather than its efficiency in treating metal-contaminated water. 
According to the studies presented, biochars produced from apricot, bamboo, cocoa husk, wheat straw, and corn straw can be substitutes for commercial activated charcoal for the removal of mercury ions in aqueous environment, as they showed very close to conventional efficiencies and very high adsorption capacity. Hence, their use may reduce costs in the treatment of wastewater containing traces of this metal.

\section{Evaluation of biochars in the removal of heavy metals in aqueous environment}

In wastewater containing traces of more than one metal, it should be used one bioadsorbent with removal efficiency for both so as to reduce treatment costs and time.

Among the biomasses used for this purpose, it can be highlighted the sugarcane residues studied by Ferreira et al. (2015), Figueredo et al. (2017), Silva (2017), and Ferreira (2018) for the removal of copper, lead, and chromium ions. The biochars produced obtained removal efficiency of $96 \%$ for lead and above 99\% for copper and chromium. There are no studies related to the production of bioadsorbents from sugarcane biomass for mercury adsorption in aqueous environment.

Studies on the removal of mercury ions from biochars were successful except for the adsorbent produced from soybeans, which showed efficiency below $75 \%$. Cocoa residues were used to produce bioadsorbent for both mercury and lead removal, being more efficient in removing mercury.

According to the survey presented, the use of sugarcane residues as bioadsorbents in heavy metal adsorption showed significant results using a low-cost, abundant, natural, and renewable biomass for high efficiency adsorption of the studied ions.

It can be concluded from this study that adsorption is a very efficient technique in removing or recovering heavy metals from the environment. This survey showed that several biomasses are being studied for biochar production aiming at the removal of metals such as copper, lead, chromium, and mercury. These biochars are alternatives that can replace commercial activated carbon because, besides having a low production cost, they have been shown to efficiently remove metal ions, ensuring an effective treatment in compliance with effluent release standards.

It is believed that the information contained in the article allows us to assess the potential of each raw material to produce biochars for environmental purposes. This information can be used in future studies on pilot projects or pilot plants improving traditional wastewater treatment systems.

\section{References}

Ali, M. H. H., \& Abdel-Satar, A. M. (2017). Removal of some heavy metals from aqueous solutions using natural wastes orange peel activated carbon. IJRDO-Journal of Applied Science, 3(3): 13-30.

Altun, T., \& Kar, Y. (2016). Removal of Cr (VI) from aqueous solution by pyrolytic charcoals. New Carbon Materials, 31(5), 501-509. doi: $10.1016 / \mathrm{S} 1872-5805(16) 60028-8$

Cha, J. S., Park, S. H., Jung, S. C., Ryu, C., Jeon, J. K., Shin, M. C., and Park, Y. K. (2016). Production and utilization of biochar: A review. Journal of Industrial and Engineering Chemistry, 40, 1-15. doi:10.1016/j.jiec.2016.06.002
Costa, D. A., Mendonça, R. H., \& Wysard Junior, M. M. (2017). Avaliação da remoção de cromo (III) por materiais compósitos porosos adsorventes de PE-g-MA, fibra de coco e quitosana, usando planejamento experimental. Engenharia Sanitária \& Ambiental, Rio de Janeiro, 22(6), 1203-1213. doi:10.1590/s1413-41522017119214

Doria Herrera, G. M., Uribe, G. C. V., Anaguano, A. H., \& Suarez, D. G. (2016). Estudio preliminar de la cascarilla de arroz modificada y su efecto en la adsorción de Cr(VI) en solución. Producción + Limpia, Caldas, 11(1), 103-116.

Eckert, C. T., Frigo, E. P., Bastos, R. K., Mari Júnior, A., Mari, A. G., \& Cabral, A. C. (2013). Biomassa Residual Vegetal. Revista Brasileira de Energias Renováveis, 4, 32-44.

Ekinci, E., Budinova, T., Yardim, F., Petrov, N., Razvigorova, M., \& Minkova, V. (2002). Removal of mercury ion from aqueous solution by activated carbons obtained from biomass and coals. Fuel Processing Technology, 77-78, 437-443. doi:10.1016/S0378-3820(02)00065-6

Figueredo, N. A., Costa, L. M., Melo, L. C. A., Siebeneichlerd, E. A., \& Tronto, J. (2017). Characterization of biochars from different sources and evaluation of release of nutrients and contaminants. Revista Ciência Agronômica, Fortaleza, 48,(3), 3-403. doi:10.5935/1806-6690.20170046

Ferreira, D. C., Da Silva, N. A., Lima, A. F., \& Begnini, M. L. (2012). Biosorção de chumbo e níquel pelas fibras do Cocos nucifera L. FAZU em Revista, Uberaba, 9, 64-68.

Ferreira, L. A. (2018). Utilização do bagaço de cana-de-açúcar como adsorvente dos íons $\mathrm{Cd}(\mathrm{II}), \mathrm{Cr}(\mathrm{III})$ e $\mathrm{Pb}(\mathrm{II})$. Instituto Municipal de Ensino Superior de Assis - IMESA, 54, Assis.

Ferreira, P. P. L., Braga, R. M., Teodoro, N. M. A., Melo, V. R. M., Melo, D. M. A., \& Melo, M. A. F. (2015). Adsorção de $\mathrm{Cu}$ (II) e $\mathrm{Cr}(\mathrm{III})$ em efluentes líquidos utilizando a cinza do bagaço da cana-de-açúcar. Cerâmica, São Paulo, 61(360). doi:10.1590/0366-69132015613601945

Geelhoed, J., Meeussen, J., Hillier, S., Lumsdon, D., Thomas, R., Farmer, J., \& Paterson, E. (2002). Identification and geochemical modeling of processes controlling leaching of $\mathrm{Cr}(\mathrm{VI})$ and other major elements from chromite ore processing residue. Geochimica et Cosmochimica Acta, 66(22), 3927-3942. doi:10.1016/S0016-7037(02)00977-8

Giri, A. K., Patel, R., \& Mandal, S. (2012). Removal of Cr (VI) from aqueous solution by Eichhornia crassipes root biomass-derived activated carbon. Chemical Engineering Journal, 185-186, 71-81. doi:10.1016/j.cej.2012.01.025

Golin, D. M. (2007). Remoção de chumbo de meios líquidos através de adsorção utilizando carvão ativado de origem vegetal e resíduos vegetais. (Dissertação de mestrado). Programa de Pós-Graduação em Engenharia de Recursos Hídricos e Minerais, Universidade Federal do Paraná, Curitiba.

Gondim, R. S., Muniz, C. R., Lima, C. E. P., \& Santos, C. L. A. (2018). Explaining the water-holding capacity of biochar by scanning electron microscope images. Revista Caatinga, 31(4), 972-979. https://dx.doi.org/10.1590/1983-21252018v31n420rc

González, P. G., \& Pliego-Cuervo, Y. B. (2014). Adsorption of Cd(II), Hg(II) and $\mathrm{Zn}(\mathrm{II})$ from aqueous solution using mesoporous activated carbon produced from Bambusa vulgaris striata. Chemical Engineering Research and Design, 92(11), 2715-2724. doi:10.1016/j.cherd.2014.02.013

Gunatilake, S. K. (2015). Methods of Removing Heavy Metals from Industrial Wastewater. Journal of Multidisciplinary Engineering Science Studies, $1(1), 12-18$.

Gupta, G. K., Ram, M., Bala, R., Kapur, M., \& Mondal, M. K. (2018). Pyrolysis of chemically treated corncob for biochar production and its application in Cr (VI) removal. Environmental Progress \& Sustainable Energy, 37(5), 1606-1617. doi:10.1002/ep.12838

Haris, H., Aris, A. Z., \& Mokhtar, M. (2017). Mercury and methylmercury distribution in the intertidal surface sediment of a heavily anthrophogenically impacted saltwater-mangrove-sediment interplay zone. $\quad$ Chemosphere, $166, \quad 323-\quad 333$. doi:10.1016/j.chemosphere.2016.09.045

Hokkanen, S., Bhatnagar, A., \& Sillanpaa, M. (2016). A review on modification methods to cellulose-based adsorbents to improve adsorption capacity. Water Research, 91, 156-173. doi:10.1016/j.watres.2016.01.008

Kede, C. M., Ndibewu, P. P., Kalumba, M. M., Panichev, N. A., Ngomo, H. M., \& Ketcha, J. M. (2015). Adsorption of Mercury(II) onto activated carbons derived from Theobroma cacao pod husk. South African Journal of Chemistry, Durban, 68, 226-235. doi:10.17159/03794350/2015/v68a31

Kim, H.; Kim, Y.; Cho, S.; Choi, W. (2012). Influence of pyrolysis temperature on physicochemical properties of biochar obtained from the 
fast pyrolysis of pitch pine (Pinus rigida). Bioresource Technology, 118 , 158-162. doi:10.1016/j.biortech.2012.04.094

Kong, H., He, J., Gao, Y., Wu, H., \& Zhu, X. (2011). Cosorption of Phenanthrene and Mercury(II) from Aqueous Solution by Soybean StalkBased Biochar. Journal of Agricultural and Food Chemistry, 59(22), 12116-12123. doi:10.1021/jf202924a

Kubilay, T., Selhan K., \& Sema B. (2014). A review of hydrothermal biomass processing. Renewable and Sustainable Energy Reviews, 40, 673-687. doi:10.1016/j.rser.2014.07.216

Lage Junior, N. C. (2016). Influência das condições de pirólise na capacidade de adsorção de íons Pb(II) pelo biochar obtido da casca de pinhão (Araucaria angustifolia). Dissertação: Programa de Pós-Graduação em Engenharia Química, UFSC, Florianópolis, Santa Catarina.

Lara, J., Tejada, C., Villabona, A., Arrieta, A., \& Conde, C. G. (2016). Adsorción de plomo y cadmio en sistema continuo de lecho fijo sobre residuos de cacau. Revista ion, Bucaramanga , 29(2), 113-124. doi:10.18273/revion.v29n2-2016009

Li, Z., Wang, F., Bai, T., Tao, J., Guo, J., Yang, M., Wang, S., \& Hu, S. (2016). Lead immobilization by geological fluorapatite and fungus Aspergillus niger. Journal of Hazardous Materials, 320, 386-392. doi:10.1016/j.jhazmat.2016.08.051

Lima, J. R. A. (2018). Remoção de metais em água utilizando Eichhornia crassipes na forma in natura, biocarvão e híbrido magnético. Dissertação de Mestrado). Universidade Federal de Sergipe, São Cristóvão.

Liu, P., Ptacek, C. J., Blowes, D. W., \& Landis, R. C. (2016). Mechanisms of mercury removal by biochars produced from different feedstocks determined using X-ray absorption spectroscopy. Journal of Hazardous Materials, 308, 233-242. doi:10.1016/j.jhazmat.2016.01.007

Lopes, C. W., Bertella, F., Pergher, S. B. C., Finger, P. H., Dallago, R. M., \& Penha, F. G. (2013). Síntese e caracterização de carvões ativados derivados do sabugo de milho. Perspectiva, Erechim. 37(139), 27-35.

Lucena, G. L., Silva, A. G., Honório, L. M. C., \& Santos, V. D. (2012). Cinética de adsorção de cobre (II) utilizando bioadsorventes. Scientia Plena, 8(9).

Melo, L. C. A., Coscione, A. R., Abreu, C. A., Puga, A. P., \& Camargo, O. A. (2013). Influence of pyrolysis temperature on cadmium and zinc sorption capacity of sugar cane straw-derived biochar. Bio Resources, 8(4), 4992-5004.

Miguel, M. F. B. (2017). Estudo de carvões ativados provenientes da pirólise de resíduos da produção e processamento de arroz: remoção de $\mathrm{Cr}(\mathrm{III})$ em meio líquido por meio de adsorção. (Dissertação de Mestrado). Faculdade de Ciências e Tecnologia - Universidade Nova de Lisboa.

Modenes, A. N., Espinoza-Quiñones, F. R., Lavarda, F. L., Colombo, A., Borba, C. E., Leichtweis, W. A., \& Mora, N. D. (2013). Remoção dos metais pesados $\mathrm{Cd}(\mathrm{II}), \mathrm{Cu}(\mathrm{II})$ e $\mathrm{Zn}(\mathrm{II})$ pelo processo de biossorção utilizando a macrófita Eicchornia crassipes. Revista Escola de Minas, Ouro Preto , 66(3), 355-362. doi:10.1590/S0370-44672013000300013

Nogueira, M. W. (2010). O uso do carvão ativado produzido a partir da casca de Moringa oleifera como adsorvente na remoção de metais pesados na presença de água. (Dissertação de Mestrado). Universidade Federal de Ouro Preto, Instituto de Ciências Exatas e Biológicas. Programa de Mestrado em Engenharia Ambiental, Ouro Preto, Minas Gerais.

Novotny, E. H., Maia, C. M. B. F., Carvalho, M. T. M., \& Madari, B. E. (2015). Biochar: pyrogenic carbon for agricultural use - a critical review. Revista Brasileira de Ciência do Solo, Viçosa , 39(2), 321-344. doi:10.1590/01000683rbcs20140818

Oliveira, Y. R. (2018). Estudo da adsorção de Cu (II) utilizando biocarvões de palha de café conilon. Dissertação (Mestrado em Agroquímica), UFES, Alegre.

Pan, J., Jiang, J., \& Xu, R. (2013). Adsorption of Cr(III) from acidic solutions by crop straw derived biochars. Journal of Environmental Sciences (China), 25(10), 1957-1965. doi:10.1016/S1001-0742(12)60305-2

Pinto, M. V. S., Silva, D. L., \& Saraiva, A. C. F. (2013). Obtenção e caracterização de carvão ativado de caroço de buriti (Mauritia flexuosa L. f.) para a avaliação do processo de adsorção de cobre (II). Acta Amazonica, 43(1). doi:10.1590/S0044-59672013000100009

Rambo, M. K. D., Schmidt, F. L., \& Ferreira, M. M. C. (2015). Analysis of the lignocellulosic components of biomass residues for biorefinery opportunities. Talanta, 144, 696-703. doi:10.1016/j.talanta.2015.06.045

Rezende, J. C. T., Nunes, D. D. A., Reis, E. N., Jesus, E., Ferraz, C., Pagano, R. L., Silva, A. S., Pacífico, J. A., \& Silva, D. C. (2014). Cinética de adsorção de $\mathrm{Cr}(\mathrm{VI})$ de soluções aquosas usando sementes de acerola. Scientia Plena, 10(10).

Rocha, W. D., Luz, J. A. M., Lena, J. C., \& Bruña-Romero, O. (2006). Adsorção de cobre por carvões ativados de endocarpo de noz de macadâmia e semente de goiaba. Revista Escola de Minas, 59(4), 409-

\section{4. doi:10.1590/S0370-44672006000400010}

Salatnik, B., Zagula, G., Bajcar, M., Tarapatskyy, M., Bobula, G., \& Puchalski, C. (2019). Biochar as a multifunctional component of the environment - A review. Applied Sciences,9, 1139. doi:10.3390/app9061139

Santos, A. M. S. (2016). Carbono ativado por pirólise a partir de biomassa de babaçu (Orbignya speciosa) e sua aplicação como adsorvente. (Dissertação de Mestrado). Universidade Federal do Piauí.

Silva, I. A. A. (2017). Síntese e avaliação da capacidade adsortiva de uma matriz adsorvente híbrida magnética usando aguapé e seu biocarvão na remediação de cadmio e chumbo. Relatório: Universidade Federal de Sergipe.

Souza, D. A. (2017). Adsorção de cobre em meio aquoso utilizando carvões ativados de casca de arroz. Dissertação Mestrado Profissional de Engenharia Ambiental. Universidade Federal do Tocantins. Palmas, Tocantins.

Souza, R. S., Carvalho, S. M. L., Garcia Júnior, M. R. L., \& Sena, R. S. F. (2009). Adsorção de cromo(VI) por carvão ativado granular de soluções diluídas utilizando um sistema batelada sob $\mathrm{pH}$ controlado. Acta Amazonica, 39(3), 661-668. doi:10.1590/S0044-59672009000300022

Tang, J., LV, H., Gong, Y., \& Huang, Y. (2015). Preparation and characterization of a novel graphene/biochar composite for aqueous phenanthrene and mercury removal. Bioresource Technology, 196, 355363. doi:10.1016/j.biortech.2015.07.047

Tejada-Tovar, C., Ortiz, A. V., \& Patenina, E. R. (2015). Cinética de adsorción de $\mathrm{Cr}$ (VI) usando biomasas residuales modificadas químicamente en sistemas por lotes y continuo. Revista Ion, Bucaramanga, 28(1), 29-41.

Tejada-Tovar, C., Montiel, Z.; \& Acevedo, D. (2016). Aprovechamiento de Cáscaras de Yuca y Ñame para el Tratamiento de Aguas Residuales Contaminadas con $\mathrm{Pb}$ (II). Información Tecnológica, 27(1), 920. doi:10.4067/S0718-07642016000100003

Trazzi, P. A., Higa, A. R., Dieckow, J., Mangrich, A. S., \& Higa, R. C. V. (2018). Biocarvão: realidade e potencial de uso no meio florestal. Ciência Florestal, Santa Maria, 28(2), 875-887. doi:10.5902/1980509832128

Tripathi, M., Sahu, J. N., \& Ganesan, P. (2016). Effect of process parameters on production of biochar from biomass waste through pyrolysis: A review. Renewable and Sustainable Energy Reviews, 55, 467-481. doi:10.1016/j.rser.2015.10.12

Zhang, Z., Wang, Z., Zhang, Z., Zhang, J., Guo, J., Li, E., Wang, X., Liu, H. \& Yan, S. (2016). Effects of engineered application of Eichhornia crassipes on the benthic macroinvertebrate diversity in Lake Dianchi, an ultra-eutrophic lake in China. Environmental Science and Pollution Research, 23(9), 8388-8397. doi:10.1007/s11356-016-6080-z

\section{License: Creative Commons CC BY 4.0}

This article was published with open access for distribution under the terms of the Creative Commons Attribution License, which allows unrestricted use, distribution, and reproduction in any medium, provided the original work is properly cited. 